\title{
Range extension of Hypostomus cochliodon Kner, 1854 (Siluriformes: Loricariidae) in Bermejo River, Salta, Argentina
}

\author{
Guillermo Enrique Terán ${ }^{1}$, Felipe Alonso ${ }^{2}$, Gastón Aguilera ${ }^{1 *}$ and Juan Marcos Mirande ${ }^{1}$ \\ 1 Unidad Ejecutora Lillo (CONICET)-Fundación Miguel Lillo, Miguel Lillo 251, San Miguel de Tucumán, CEP 4000, Tucumán, Argentina \\ 2 Museo Argentino de Ciencias Naturales "Bernardino Rivadavia” (MACN)-CONICET, División Ictiología, Av. Ángel Gallardo 470, Buenos \\ Aires, CEP 1405, Argentina \\ * Corresponding author. E-mail: gaguilera@lillo.org.ar
}

\begin{abstract}
Hypostomus cochliodon Kner, 1854 had been recorded from Paraguay and Paraná rivers in Argentina. We recorded for the first time specimens of $H$. cochliodon to the Bermejo River basin. It is also the first record of this species to Salta province, Argentina.
\end{abstract}

Key words: biogeography; distribution; northwestern Argentina; first record; Hypostominae

The Loricariidae include over 900 species in 70 genera, being the most diverse family within Siluriformes (Eschmeyer and Fong 2015). This family includes species with the body covered by bony plates and showing a great diversity of size, from the smallest Nannoplecostomus eleonorae Ribeiro, Lima \& Pereira, 2012 (about 9 mm SL) to the largest forms, such as the ancistrine Pseudacanthicus histrix (Valenciennes, 1840) (reaching $900 \mathrm{~mm} \mathrm{SL}$ ).

Within Loricariidae, Hypostominae is the most species-rich subfamily and the most geographically widespread (Eschmeyer and Fong 2015). Armbruster (2004), after a phylogenetic analysis of the Hypostominae, considered Cochliodon Heckel, 1854 as synonym of Hypostomus Lacépède, 1803.

Hypostomus is one of the most diverse loricariid genera, including about 130 valid species (Eschmeyer et al. 2015). This genus has a wide distribution in the Neotropical basins, occurring from Central America to La Plata River in Argentina.

Species of the Hypostomus cochliodon group, along with Panaque Eigenmann \& Eigenmann, 1889, are distinctive among fishes by feeding on wood as the major part of the diet (Schaefer and Stewart 1993; Armbruster 2003). Those species share the presence of large spoon-shaped teeth, which was independently acquired in Panaque and the $H$. cochliodon group, according to the hypothesis of Armbruster (2004).

Currently, 20 valid nominal species are included in the H. cochliodon group (Armbruster 2003; Tencatt et al. 2014). In Argentina, this group is represented only by Hypostomus cochliodon Kner, 1854, which was described from the Cuiabá River basin, Brazil (Kner 1854: 265) but can be found along the Paraguay and Paraná rivers (Armbruster 2003; Weber 2003; Zawadzki et al. 2005; Graça and Pavanelli 2007; Tencatt et al. 2014; Almirón et al. 2015).

The Bermejo River is one of the most important hydrographic systems of Argentina and one of the most important tributaries of the Río de la Plata system. A recent collecting expedition to northwestern Argentina allowed us to record Hypostomus cochliodon from the upper Bermejo River basin (Figure 1).

Morphometric measurements were taken following Tencatt et al. (2014); they were taken with a caliper to nearest $0.01 \mathrm{~mm}$, are straight lines between two points, and expressed as percentage of standard length (SL) and head length (HL).

Specimens herein reported were collected after intense fieldwork in the upper Bermejo River basin, done under permit (Number 335/15 and 594/15, issued by Secretaría de Ambiente of Salta province). Specimens were captured using hand nets. Voucher specimens were euthanized by an overdose in benzocaine solution, fixed in $4 \%$ formalin solution for 7 days and preserved in $70 \%$ ethanol.

Institutional abbreviation: CI-FML. Ichthyological collection of Fundación Miguel Lillo.

Examined material. CI-FML 7091, 10 specimens, 55.2-230.0 mm

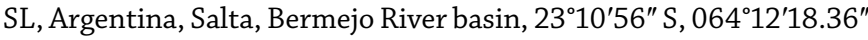
W, September 2015, Mirande, Aguilera, Alonso, and Terán. CI-FML 7092, 1 specimen, 75.8 mm SL, Argentina, Salta, San Ramón de la Nueva Orán, Aguas Lindas stream, Bermejo River basin, 2300'53" S, $064^{\circ} 21^{\prime} 54^{\prime \prime}$ W, September 2015, Mirande, Aguilera, Alonso, and Terán. CI-FML 7093, 2 specimens, 51.4-100.8 mm SL, Argentina, Salta, San Ramón de la Nueva Orán, unnamed stream between Pescado and Blanco River, Bermejo River basin, $23^{\circ} 01^{\prime} 33^{\prime \prime} \mathrm{S}$, 

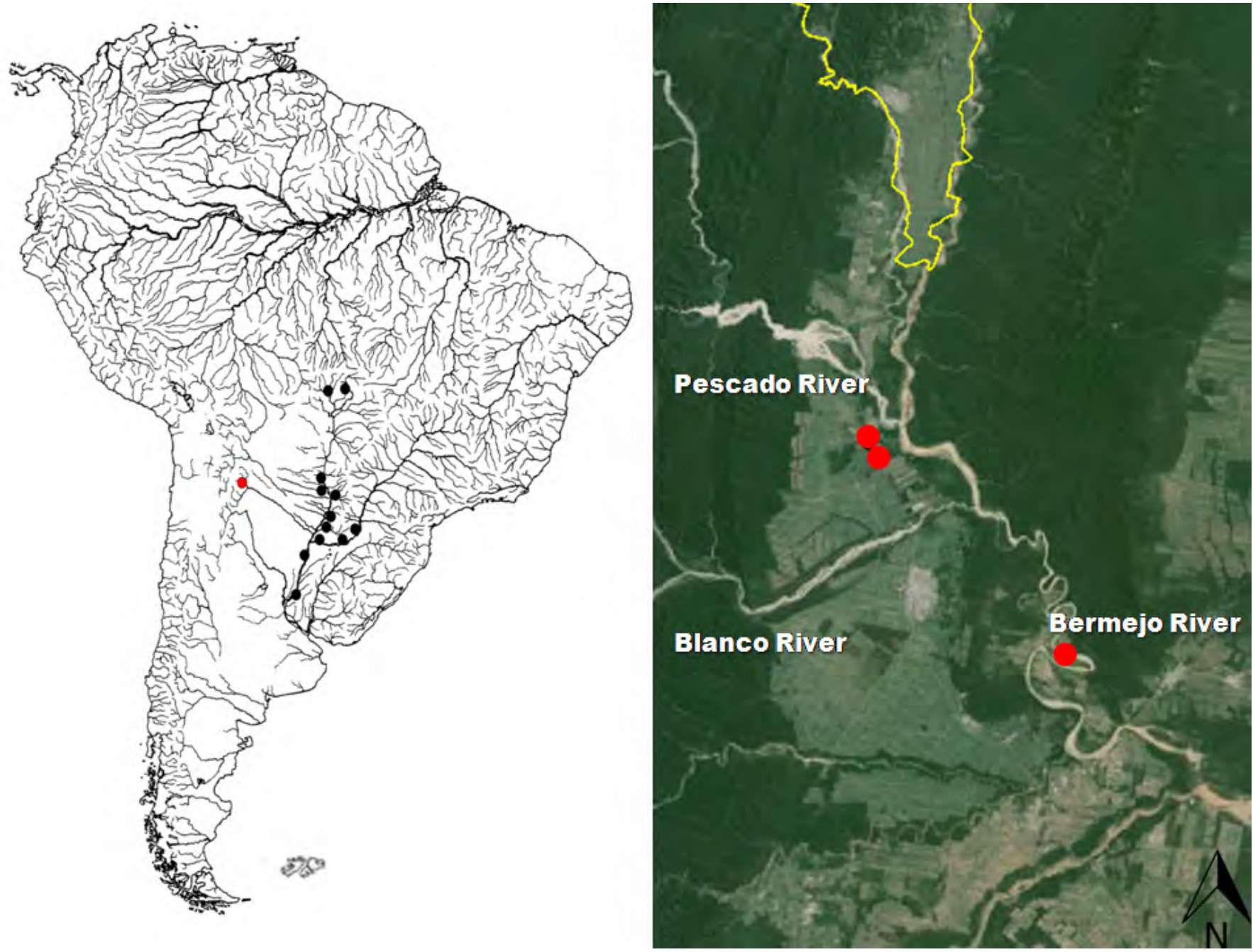

Figure 1. Sites of Hypostomus cochliodon in Bermejo River basin, Salta province, Argentina.

064²1'37" W, May 2015, Mirande, Alonso and Terán. CI-FML 7150, 2 specimens, 49.3 and $293.0 \mathrm{~mm}$, Argentina, Salta, Embarcación,

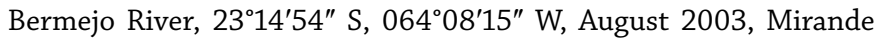
and Aguilera.

According to Tencatt et al. (2014), Hypostomus cochliodon can be distinguished from the other species of the H. cochliodon group by the following characters: 1 ) opercle almost completely covered by a thick layer of skin and exposed region not easily visible; 2) absence of buccal papillae; 3) presence of weak to moderately developed keels on lateral plates; 4) presence of small dark spots closely-set on head and larger, widely spaced spots on trunk, with caudal peduncle generally without spots; 5) caudal-fin lobes evenly colored; 6) bicuspid teeth with a large spoon-shaped mesial cusp and inconspicuous lateral cusp that is generally fused to mesial cusp; 7) absence of a longitudinal dark stripe along midline of flank; and 8) presence of an adipose fin. All these characters are shared by the specimens collected at the Bermejo River basin (Figures 2-4), allowing us to identify them as $H$. cochliodon.

As it was reported by Tencatt et al. (2014), the coloration pattern is highly variable in this species with some individuals more spotted than others. Such variation was also found in the specimens from the Bermejo River basin.

The coloration in life of one of the collected specimens showed a stress color pattern (Figure 4) in which the individual is very dark with black stripes dorsally. This is frequently observed in life (Tencatt pers. com.), but this coloration is lost after fixation. Color changes may be important for communication and intra- or interspecific signaling in Loricariidae, and it would be interesting to investigate its relationship with reproduction, physiology and agonistic behaviors.

Morphometric measurements of $H$. cochliodon from the Bermejo River basin are provided in Table 1.

After an intensive sampling performed at northwestern Argentina in the Bermejo River basin, the main western tributary to the Paraguay-Parana system, we collected specimens identified as Hypostomus cochliodon, according to the diagnosis provided by Tencatt et al. (2014). Those new records for this basin considerably extend the known distribution range of this species and also represent the first record for $H$. cochliodon in the Yungas province (sensu Morrone 2014) and the highest 

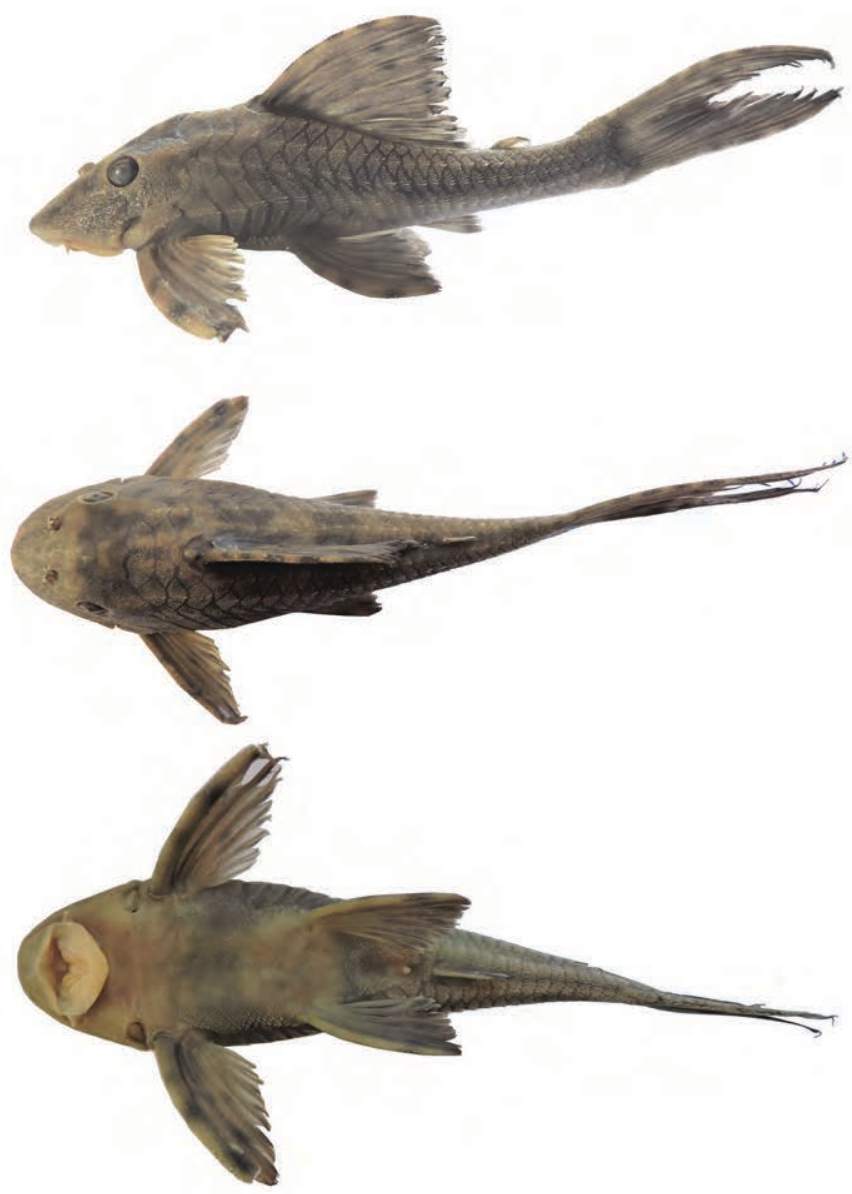

Figure 2. Hypostomus cochliodon, Cl-FML 7091, 86.1 mm SL, Bermejo River, Salta province, Argentina; lateral, dorsal, and ventral views. altitude (350 $\mathrm{m}$ above sea level) recorded for this species, in addition to the first record for Salta province.

The upper Bermejo River basin has rocky bottoms and moderately fast to fast-flowing waters that run from west to east through the Andes to the chacoan plain. Rains are mainly concentrated in summer and most rivers in the area have a highly torrential regime during that period with high amounts of suspended particles and turbidity, while the volume of water is considerably diminished during the rest of the year

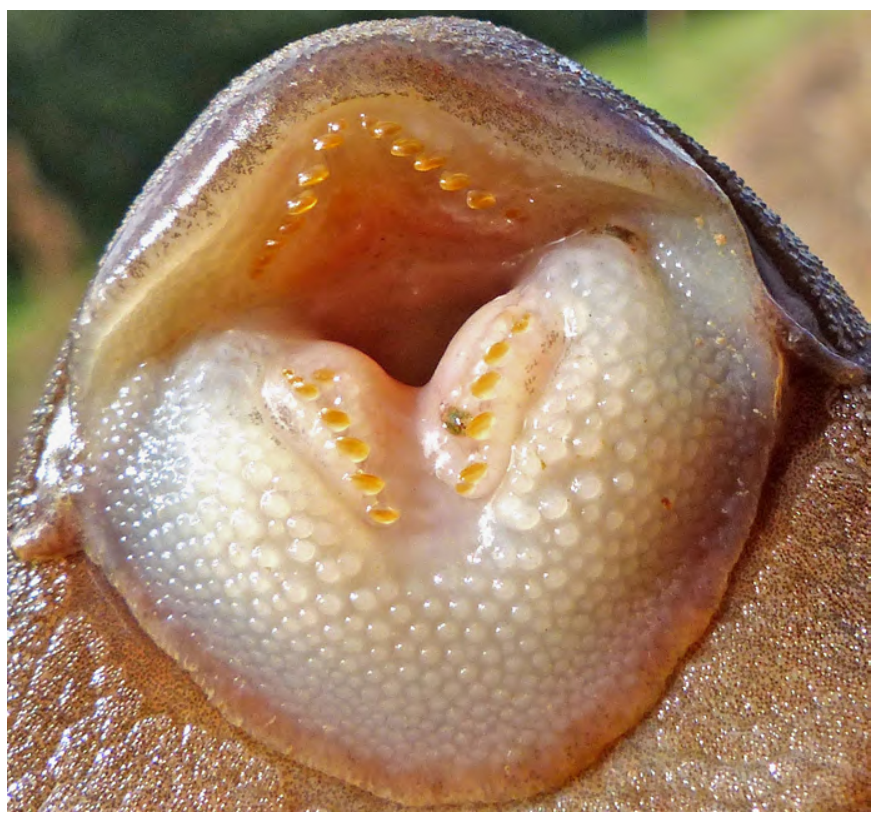

Figure 3. Hypostomus cochliodon, $\mathrm{Cl}-\mathrm{FML} 7093,100.8 \mathrm{~mm}$ SL, live specimen, Bermejo River, Salta province, Argentina. Teeth in detail.

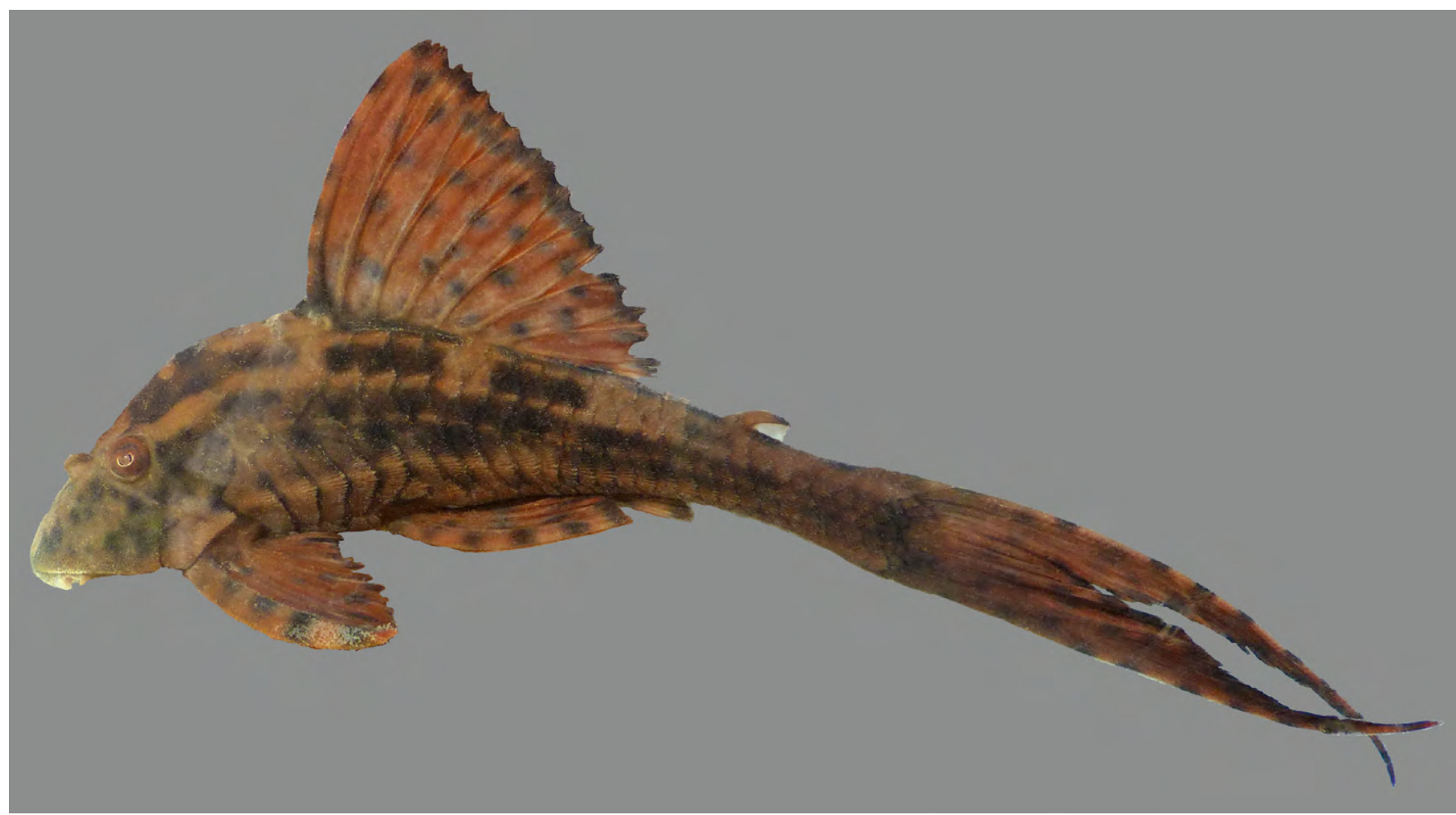

Figure 4. Hypostomus cochliodon, CI-FML 7093, 100.8 mm SL, live specimen, Bermejo River basin, Salta province, Argentina. 
Table 1. Morphometric measurements of Hypostomus cochliodon, $\mathrm{Cl}-\mathrm{FML}$ 7091-7093, from Bermejo River basin, Salta, Argentina $(n=13)$. SD = standard deviation.

\begin{tabular}{llll}
\hline & Range & Mean & SD \\
\hline Standard length (mm) & $51.5-230.0$ & 88.5 & 47.5 \\
\hline Percentage of standard length & & & \\
Predorsal length & $37.3-45.4$ & 42.5 & 2.0 \\
Head length & $29.3-38.7$ & 35.0 & 2.9 \\
Interdorsal distance & $15.1-18.5$ & 16.8 & 1.1 \\
Thoracic width & $21.4-23.9$ & 22.5 & 0.7 \\
Abdominal width & $19.7-21.8$ & 20.7 & 0.6 \\
Caudal peduncle length & $24.2-34.9$ & 31.8 & 2.6 \\
Caudal peduncle depth & $8.7-10.3$ & 9.2 & 0.4 \\
Dorsal-fin spine length & $20.7-36.7$ & 32.6 & 4.3 \\
Dorsal-fin base length & $23.0-29.2$ & 25.9 & 1.9 \\
Pectoral-fin spine length & $26.8-32.0$ & 29.2 & 1.5 \\
Pelvic-fin spine length & $23.5-26.7$ & 25.1 & 1.0 \\
Upper caudal-fin ray length & $32.5-49.5$ & 42.9 & 5.1 \\
Lower caudal-fin ray length & $30.6-51.2$ & 46.3 & 6.1 \\
Adipose-fin spine length & $6.1-8.8$ & 7.1 & 0.8 \\
Cleithral width & $28.1-31.1$ & 29.8 & 0.9 \\
\hline Percentage of head length & & & \\
Head depth & $55.5-77.0$ & 61.0 & 6.2 \\
Snout length & $58.3-73.7$ & 62.7 & 3.7 \\
Interorbital width & $43.8-55.6$ & 48.4 & 2.8 \\
Orbital diameter & $12.2-19.1$ & 16.5 & 1.8 \\
Lower lip width & $39.0-49.3$ & 43.2 & 2.7 \\
Lower lip length & $11.4-17.9$ & 14.9 & 1.6 \\
Maxillary barbel length & $8.0-12.3$ & 9.5 & 1.3 \\
\hline & & & \\
\hline & & & \\
\hline
\end{tabular}

when water is very clear and transparent. Most streams in the upper Bermejo River basin, in the lower portion of the Yungas, where $H$. cochliodon was collected, have abundant marginal vegetation and rocky bottoms. When the Bermejo River reaches the chaco-pampean plain, near the city of Embarcación in Salta, a sudden ecological change is observed; the bottom is muddy, driftwood is abundant and the water is turbid, with a great amount of solids in suspension the whole year, although in the dry season water is less turbid (Alonso and Terán pers. obs.). This great ecological change may represent a geographic barrier for many species, which is reflected in the high levels of endemism observed in the Yungas area (e.g., Casciotta and Almirón 2004; Mirande et al. 2004a, 2004b, 2006, 2011; Rodríguez and Miquelarena 2005; Miquelarena and Menni 2005; Calviño and Alonso 2009). Nevertheless, many species are shared between the upper Bermejo River basin and the remaining Paraná-Paraguay basins such as the case of $H$. cochliodon or, for example, Astyanax lacustris, A. lineatus, and Cichlasoma dimerus, among many others, reported by Gonzo (2003), Mirande and Aguilera (2009), and Aguilera et al. (2016).

This new record highlights the importance of biodiversity survey projects in poorly know ecosystems and should be taken into account for conservation and resource extraction in the basin.

\section{ACKNOWLEDGEMENTS}

We are grateful to Luiz Tencatt for helping us on the identification of this species, and valuable comments on the coloration pattern variation. We thank the Fundación Miguel Lillo, CONICET, and FONCyT (PICT 2011-0992 and 2012-2683; PIP 0301) for constant support. Two reviewers improved the manuscript with comments and suggestions.

\section{LITERATURE CITED}

Aguilera, G., G.E. Terán, F. Alonso and J.M. Mirande. 2016. First record of the banjo catfish Bunocephalus doriae Boulenger 1902 (Siluriformes: Aspredinidae) in the Bermejo River basin, Salta, Argentina. Check List 12(3): 1888. doi: 10.15560/12.3.1888

Almirón, A., J. Casciotta, L. Ciotek and P. Giorgis. 2015. Guía de los peces del Parque Nacional Pre-Delta, 2nd ed. Buenos Aires: Administración de Parques Nacionales Ciudad Autónoma de Buenos Aires. 300 pp.

Armbruster, J.W. 2003. The species of the Hypostomus cochliodon group (Siluriformes: Loricariidae). Zootaxa 249: 1-60. http:// www.mapress.com/zootaxa/2003f/zt00249.pdf

Armbruster, J.W. 2004. Phylogenetic relationships of the suckermouth armored catfishes (Loricariidae) with emphasis on the Hypostominae and the Ancistrinae. Zoological Journal of the Linnean Society 141: 1-80. doi: 10.1111/j.1096-3642.2004.00109.x

Calviño, P.A. and F. Alonso. 2009. Two new species of the genus Corydoras (Ostariophysi: Siluriformes: Callichthyidae) from northwestern Argentina, and redescription of C. micracanthus Regan, 1912. Revista del Museo Argentino de Ciencias Naturales "Bernardino Rivadavia" 11(2): 199-214. http://revista.macn.gob. ar/ojs/index.php/RevMus/article/view/260/244

Casciotta, J.R. and A.E. Almirón. 2004. Astyanax chico sp. n. - a new species from the río San Francisco basin, northwest of Argentina (Teleostei: Characiformes: Characidae). Zoologische Abhandlungen (Dresden) 54: 11-17.

Cuvier, G. and A. Valenciennes. 1840. Histoire naturelle des poissons. Tome quinzième. Suite du livre dix-septième. Siluroïdes 15: 1-540. http://biodiversitylibrary.org/page/4445153

Eigenmann, C.H. and R.S. Eigenmann. 1889. Preliminary notes on South American Nematognathi. II. Proceedings of the California Academy of Sciences 2: 28-56. http://www.biodiversitylibrary. org/page/7133491

Eschmeyer, W. N., R. Fricke and R. van der Laan (eds). Catalog of fishes: genera, species, references. Accessed at http:// researcharchive.calacademy.org/research/ichthyology/catalog/ fishcatmain.asp, October 2015.

Eschmeyer, W.N. and J.D. Fong. 2015. Species by family/subfamily in the Catalog of Fishes. Accessed at http://researcharchive. calacademy.org/research/ichthyology/catalog/SpeciesByFamily. asp, October 2015.

Monasterio de Gonzo, G. 2003. Peces de los ríos Bermejo, Juramento y Cuencas Endorreicas de la Provincia de Salta. Salta: Museo de Ciencias Naturales y Consejo de Investigación, Universidad de Nacional de Salta. Salta. 243 pp.

Graça, W.J. and C.S. Pavanelli. 2007. Peixes da planície de inundação do alto rio Paraná e áreas adjacentes. Maringá: Editora da Universidade Estadual de Maringá. 241 pp.

Kner, R. 1854. Die Hypostomiden. Zweite Hauptgruppe der Familie der Panzerfische. (Loricata v. Goniodontes). Denkschriften der Kaiserlichen Akademie der Wissenschaften in Wien, Mathematisch-Naturwissenschaftliche Classe, Wien 7: 251-286. doi: 10.5962/bhl.title.12573

Lacépède, B.G.E. 1803. Histoire naturelle des poissons 5: 1-803. 
http://biodiversitylibrary.org/page/12842754

Miquelarena, A.M. and R.C. Menni. 2005. Astyanax tumbayaensis, a new species from northwestern Argentina highlands (Characiformes: Characidae) with a key to the Argentinean species of the genus and comments on their distribution. Revue suisse de Zoologie 112: 661-676. http://www.biodiversitylibrary.org/ page/ 41226545

Mirande, J.M., G. Aguilera, and M.M. Azpelicueta. 2004a. A new species of Astyanax (Characiformes, Characidae) from the upper río Bermejo basin, Salta, Argentina. Revue Suisse de Zoologie 111: 213-224. http://www.biodiversitylibrary.org/page/41187309

Mirande, J.M., G. Aguilera, and M.M. Azpelicueta. 2004b. A new genus and species of small characid (Ostariophysi, Characidae) from the upper Río Bermejo basin, northwestern Argentina. Revue suisse de Zoologie 111: 715-728. http://www. biodiversityheritagelibrary.org/page/41227675

Mirande, J.M., G. Aguilera, and M.M. Azpelicueta. 2006. Astyanax endy (Characiformes: Characidae), a new fish species from the upper Río Bermejo basin, northwestern Argentina. Zootaxa 1286: 57-68.

Mirande, J.M., G. Aguilera, and M.M. Azpelicueta. 2011. A threatened new species of Oligosarcus and its phylogenetic relationships, with comments of Astyanacinus (Teleostei: Characidae). Zootaxa 2994: 1-20

Mirande, J.M. and G. Aguilera. 2009. Los peces de la selva pedemontana del noroeste argentino; pp. 169-211, in: A. Brown, P.G. Blendinger, T. Lomáscolo and P. Garcia Bes (eds.). Selva Pedemontana de las Yungas. Historia natural, ecología y manejo de un ecosistema en Peligro. Yerba Buena Tucumán: Ediciones del Subtrópico. http://proyungas.org.ar/wpcontent/uploads/2014/12/ SelvaPedemontanadelasYungas.pdf

Morrone, J.J. 2014. Biogeographical regionalisation of the Neotropical region. Zootaxa 3782: 1-110. doi: 10.11646/zootaxa.3782.1.1

Ribeiro, A.C., F. C.T. Lima and E.H.L. Pereira. 2012. A new genus and species of a minute suckermouth armored catfish (Siluriformes:
Loricariidae) from the Rio Tocantins drainage, central Brazil: the smallest known loricariid catfish. Copeia 2012(4): 637-647. doi: 10.1643/CI-11-137

Rodríguez, M.S. and M.A. Miquelarena. 2005. Una nueva especie de Loricaria (Siluriformes: Loricariidae) para la cuenca del río San Francisco, Jujuy, Argentina. Anales de la Academia Nacional de Ciencias Exactas, Físicas y Naturales 55: 139-149.

Schaefer, S.A. and D.J. Stewart. 1993. Systematics of the Panaquedentex species group (Siluriformes: Loricariidae), wood-eating armored catfishes from tropical South America. Ichthyological Exploration of Freshwaters, 4: 309-342.

Tencatt, L.F.C., C.H. Zawadzki, and F. Otávio. 2014. Two new species of the Hypostomus cochliodon group (Siluriformes: Loricariidae) from the Rio Paraguay basin, with a redescription of Hypostomus cochliodon Kner, 1854. Neotropical Ichthyology 12(3): 585602. doi: 10.1590/1982-0224-20130162

Weber, C. 2003. Subfamily Hypostominae (Armored catfishes); pp. 351-372, in: R.E. Reis, S.O. Kullander and C.J. Ferraris (eds.). Check list of the freshwater fishes of South and Central America. Porto Alegre: EDIPUCRS. 729 pp.

Zawadzki, C.H., E. Renesto, R.E. Reis, M.O. Moura, and R.P. Mateus. 2005. Allozyme relationships in hypostomines (Teleostei: Loricariidae) from the Itaipu Reservoir, Upper Rio Paraná basin, Brazil. Genetica 123: 271-283. doi: 10.1007/s10709-004-5418-5

Author contributions: GET wrote the note and analyzed the specimens, GA took the measurements, FA made the map, and JMM compared the specimens with the related species. GA and FA photographed the specimens. All authors contributed to write the manuscript.

Received: 25 November 2015

Accepted: 27 July 2016

Academic editor: Bárbara Calegari 